Bacteriological control on Sterilized water units of the Operationroom

\title{
手術用滅菌水の細菌学的管理
}

広島大学医学部附属病院手術部

芦山辰朗

最初にまずお断りしておかなければ，ならな いことは，私は細菌学を専攻しているものでは ないといらことです。

演題には細菌学的管理となっていますが, 手 術室で用いられるような, かなり良質の水の細 菌污染の一般論やその管理について微生物側か らの検討は, 非常に多くの問題と広範な研究を 基礎にしたものでなければならないと考えま す.

一般論としては，とうてい私などの手におえ るものではないと思いますが，わが国の病院に 今まで設置していた手術室用滅菌水製造装置か ら得られる水が多くの病院で污染していたとい らことから，数年前にこの問題を検討して発表 いたしました。

その後, この問題はさまざまな機会に討論さ れ研究されてきました.

われわれもこのことを発表して以来, 装置の 改修の技術的な課題と予算獲得の困難さから 2 年余にわたり根本的な改善を行ない得ずにすご してきましたが，ようやく本年 3 月に改修を終 わりました。

爾来，6力月以上になりますが，細菌污染か ら開放され，1回も菌を検出することがなくな りましたので，改修に当たりどのよらなことを 考え，具体的にどうしたかというようなことを お話し申し上げ，ご参考に供したいと思いま 于.

技術的な問題の検討の前に，このような課題 を解決する場合, ほとんどの病院でいつも起こ ってくるのは，予算がないということ，このこ とに少しふれておく必要があるかと思います。
優秀な機能をもった完全な装置を開発し設置 することによって，こうした問題を解決するこ とは，それほど困難ではないと思いますが，問 題は現在わが国の各病院で院内感染対策がどれ ほど真剣に取扱われているかといらことだろう と思います。

術後感染症をはじめとして, 病院内感染がい かにひどいかは, 公然の秘密になっていると明 確に指摘した論説もあるぐらいです。

入院した患者のより良き医療のために，また 治療に関与する医療従事者の健康と安全のため にも，院内感染対策として早急に改善すべき問 題が山積みしています.

このことは単に予算が足りないとか，管理者 の認識不足とかにのみ帰すべきではなく, 必要 な施設や設備, さらにはそれらの運用管理が重 要であること，そのための費用や施策を具体化 するようにとの運動を起こす必要があります。

行政担当者にあるべき姿を説き，予算面で も, 実行面でも1歩でも 2 歩でも前進さすこと がわれわれ現場をあずかるものの責任でもあ ると考えます。

どのような設備が最小限必要であるか，少な くともこれだけの設備はそなえるべきで，その 運転管理はどのように行なうべきであるかなど についての研究と資料が常に提示されなければ このような運動はなかなか進展しないと考えま 于.

世はあげて公害論争にあけくれていますが， 病院に括いても, 直接の医療行為の花々しい成 果に目をうばわれ，それに追従するのみという ことで，その成り立つ背影の十分な分析と反省 
がなければ，産業社会において問題となった生 産第一主義がもたらした公害発生企業のような 性格が，大病院ほど進行することになります。

このことはすでに 1800 年代の中ごろ，イギリ スで小さい診療所に比してベッド数の多い大病 院ほど，院内感染率が高くそれにともなう死亡 率が高いことが報告され，病院規模が大きいほ ど，厳重な感染防止が行なわなければならない ことが強調されています。

\section{1. 病院における水の污染}

院内感染という立場から考えますと，病院に おいて, 手術前の手洗い用滅菌水や消毒㓮の稀 釈用水が細菌学的に污染しているということは きわめて由々しい問題であります。

1969年の Lancet に Shooter という人がロン ドンのある病院で緑膿菌の腸管への侵入経路に ついて調查した際, 病室の薬瓶 173 本中, 薄荷 水の 20 本全部が緑膿菌で污染されており，ただ ちに回収したが，4 人の患者がすでにそれを飲 んでおり䔬便検查で 4 人とも菌が陽性であった ということを報告しています。

病院内感染でしばしば問題になる緑膿菌にし ても，その発生源，移行経路の追求がなされな ければ，その根本的な対策は樹立できないと考 えます。

手術用滅菌水から検出される菌の性質につい ては，前に医科器械学雑誌に発表いたしました が，久留米の萩原等は減菌水中から検出された 菌は水道水やかなり良質の水中で発育する無機 栄養菌で，脱イオン水中では発育が阻止された と報告しています。

滅菌水の無菌試験をやっていまして，比較的 よく検出されるのは，前に発表しました Gram 陰性の桿菌ですが，時に緑膿菌も出現します。

調查しました，ある病院の手洗い用滅菌水か ら検出された緑膿菌を, 水道水, 手洗い用滅菌 水（装置を改良してからのもので蒸溜水）と中 央検查部の蒸溜水の 3 種の水中で培養してみた ところ，1 週間たっても，2 週間たってもそれ ぞれの水中で死滅しません．

100.日たっても試験管の混濁度も沈渣にも変 化なく菌数もほとんどそのまま維持され，平板

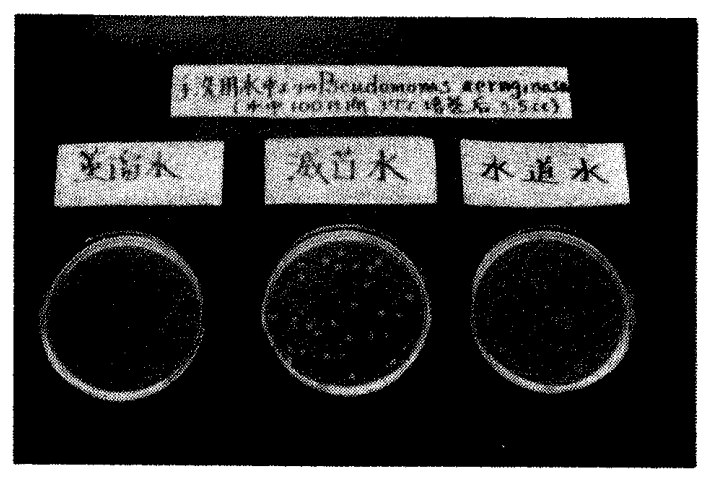

図 1

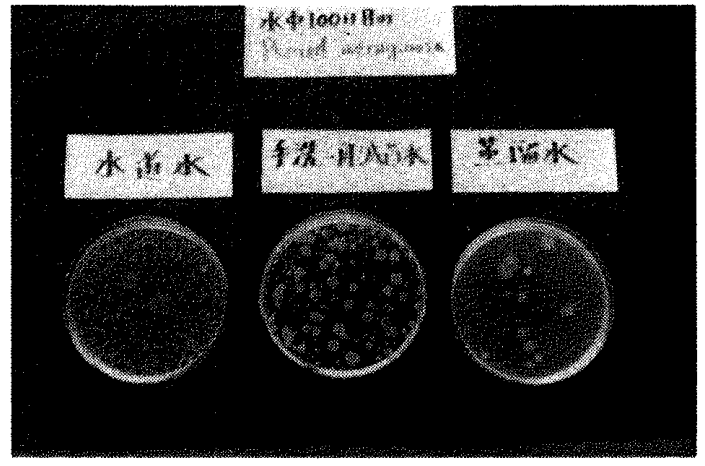

图 2

への塗沫で，コロニーの性質が変わりません． この菌がきわめて水に親和性の強いことがよく わかりました。

図 1,2 は 100 日後の水を $0.5 \mathrm{cc}$ とりハートイ ンフュージョンに混釈培養して，24時間，48時 間後の状態で，水によってコロニー形成の差が みられ，水道水中のものが最も標準的なコロニ 一形成を示すようです.

培地となった水の $\mathrm{pH}$ は，手術室の滅菌水が 7.28 が 7.31 に，中央検查部の蒸溜水が7.36から 7.42 に，水道水が 7.45 から 7.35 に変化しており ます。

一方，滅菌水製造装置を設置した部屋の污染

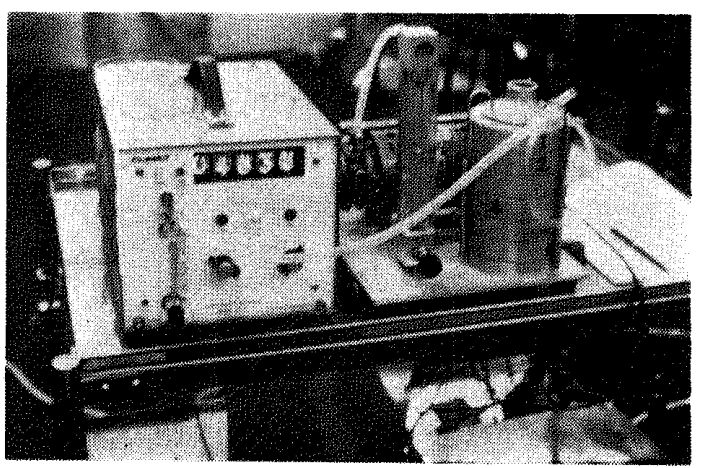

図 3 Partical Counter と Andersen Air Sampler 
度は,なんらかの意味で水の污染と関連がある かと思って，これを調べてみました。

従来, 室内空気の污染度は一般に落下細菌数 で表現されていましたが，最近われわれは，図 3のよ5ないろいろな器具を用いて空気中の 塵埃量や細菌数と落下細菌数の関係などを調 ベています. 左端のものは, Climet の Particle Counter Model CI-250であります. この計器 は $0.1 \mathrm{cf}$ と $0.01 \mathrm{cf}$ の空気中の塵埃を粒径 $0.5 \mu$ 以上, $1.0 \mu$ 以上, $2.0 \mu$ 以上, $5.0 \mu$ 以上, 10.0 $\mu$ 以上の別にデジタルで塵埃数として表現して くれます。

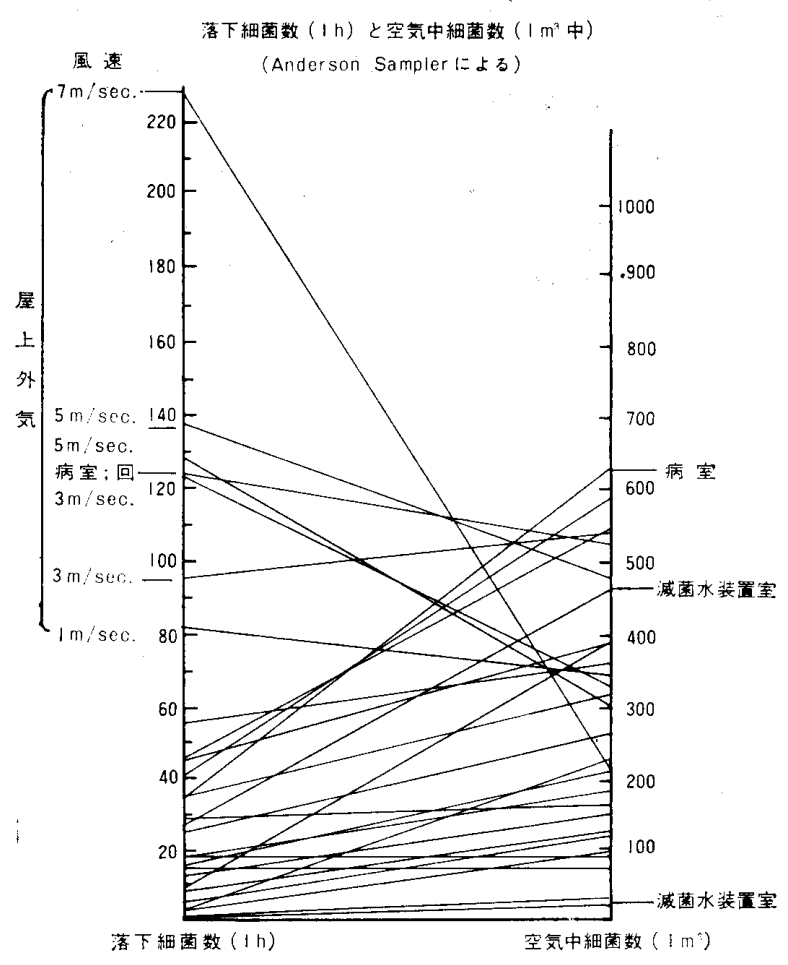

図 4 落下菌数 と $1 \mathrm{~m}^{3}$ 中菌数

隣のアルミ製の円筒型の 6 段に分かれたの が，アンダーセンのエアーサンプラーで, 各段 に一定量の培地を流した $9 \mathrm{~cm}$ 径のシャーレを 入れ, 装置を運転しますと, サイズ別に 6 段階 に分けて空気中の細菌を捕獲することができま す.

図 4 の滅菌水装置室と書いてあるのがそれ で, $1 \mathrm{~m}^{3}$ 空気中に 462 といら成績でした. 1 時 間当たりのこの時の落下細菌数は28で，これら は培地にハートインフュージョンを用いたもの です.
サブロ一の培地を用いたものでは, $1 \mathrm{~m}^{3}$ 中に 202 , 落下細菌数， 1 時間当り 27 となりました. 図の下の滅菌水装置室と書いていますのは，良 く管理された他の病院のものです.

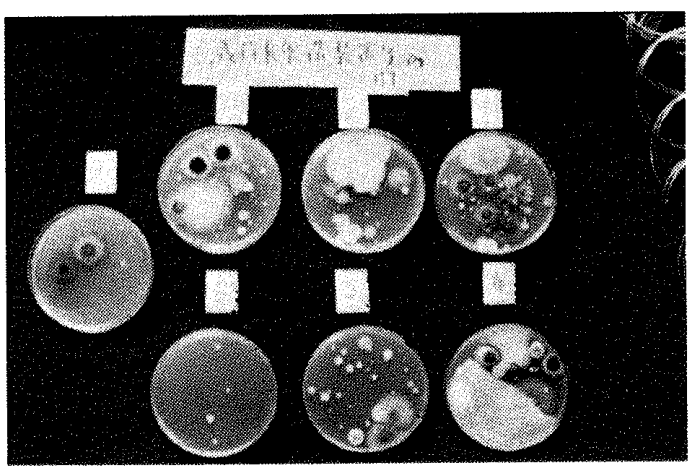

图 5 隇菌水彆造装置室内菌

図 5 はこうして採取した空気中の細菌のコロ ニーですが，これらの菌の中に滅菌水製造装置 内に侵入増殖してくるものが，捕獲されてはい まいかと考え，各々のシャーレに発育したコロ ニーを混合して各シャーレごとに培養いたしま した.

水道水を培地として $50^{\circ} \mathrm{C}$ で72時間培養し，そ の $0.5 \mathrm{cc}$ をハートインフュージョンに混合稀䣋 して，24時間培養するという操作を 2 回くりか えして発育してきたのが，図6です.

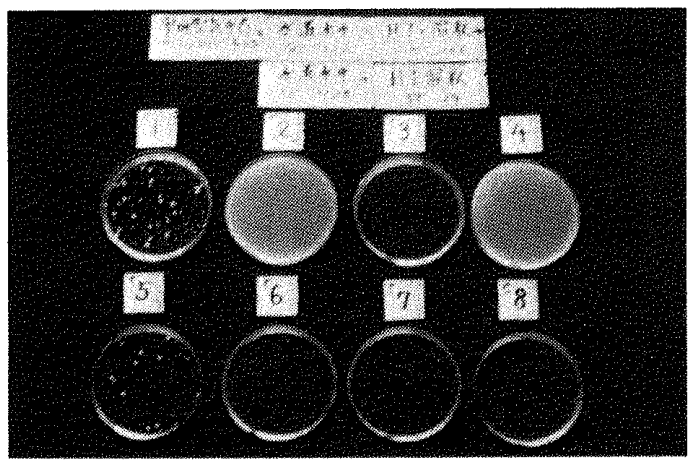

図 6 室内菌 $\rightarrow$ 水道水 $\rightarrow \mathrm{HI} \rightarrow$ 水道水 $\rightarrow \mathrm{HI}$

こうして処理しますと, No. 1, 2, 4, 5 のシャ ーレからは菌を検出しましたが，他のシャーレ のものは, 水道水が培地であるといらこと, $50^{\circ} \mathrm{C}$ で72時間が 2 回くりかえされるという条件で淘 汰されました。

こうして残った菌は 2 種類で，1 1 つ枯草菌 で，今 1 種は，糖を分解しない Gram 陰性の桿 菌でした．それ以上の同定をやっていません が，以前に発表した滅菌水から検出したものに 
かなり類似した性質をもっているように思いま す.

明確な裏付けにはなりませんが減菌水装置内 污染の原因が環境の空気中から由来するもので はないかとの推測の一助になるかと考えます.

以上のように精製した水でも細菌污染の機会 さえあれば，細菌は発育してくることが可能な わけで，極めて精度の高い蒸溜水で西るから細 菌溌育しないのではあるまいか；㐫るいは増 殖を阻止するだろうというような安易な考えは 成り立たないと考えます。

\section{2. 装置の改良計画}

以上のようなことを基礎に手術室用滅菌水製 造装置の改修を計画したのでありますが，先ず 問題になるのは, 手術室で使用する水はどの程 度まで

精製すべきか

どの程度の製造能力をもち

貯水すべきかどうか

貯水するとすれば，どれだけの量を貯水すべ きか

最後にその水が細菌学的にどのように密封さ れるべきか，ということだろうと思います。

ご存知のように手術室の滅菌水の用途は, 手 洗い用，消毒剂の稀䣋用，創面や膀胱，腔など の洗浄用や, 器械器具の洗浄用, 酸素療法やネ
ことが良いということで，蒸溜水を用いること にしました。

次で製造量と貯水量については，各病院の実 状から決定すべきでありますが，あとで説明い たしますが，毎時 $70 l$ の製造と $400 l$ の貯水量 ということにしました。

これは装置や配管等を新らたに構想するとい うことでなく，現在の装置を改修するというこ とで，貯水槽とそれ以下の配管は既設のものを そのまま利用したこととも関連があります.

最後の滅菌水装置からの水に細菌の発育, 増 殖をみるということへの対策は，装置内に菌が 侵入増殖するわけでありますから，とにかく装 置内人の侵入経路の遮断を行なら必要がありま す. 侵入路としては，水源の污染が不完全な殺 菌によってそのまま持ちこまれる場合，これは

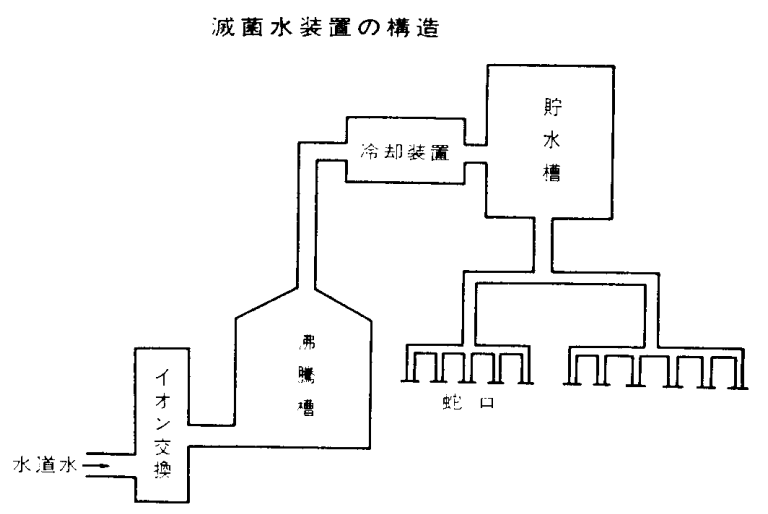

図 7 ブライザーの加湿用, 病 院によっては, 注射器, 輸液セット，イルリガー トル，人工心肺回路, 各 種のカテーテルや瓶など の容器の洗浄後のすすぎ に用いられたりします。

このような用途から考 えるとそれが無菌である ことは勿論であります が，同時に発熱物質を含 まないこと，また消毒剤 の薬効に対する各種イオ ンによる効力の減退とい うような点から, 出来る だけ精製された水である

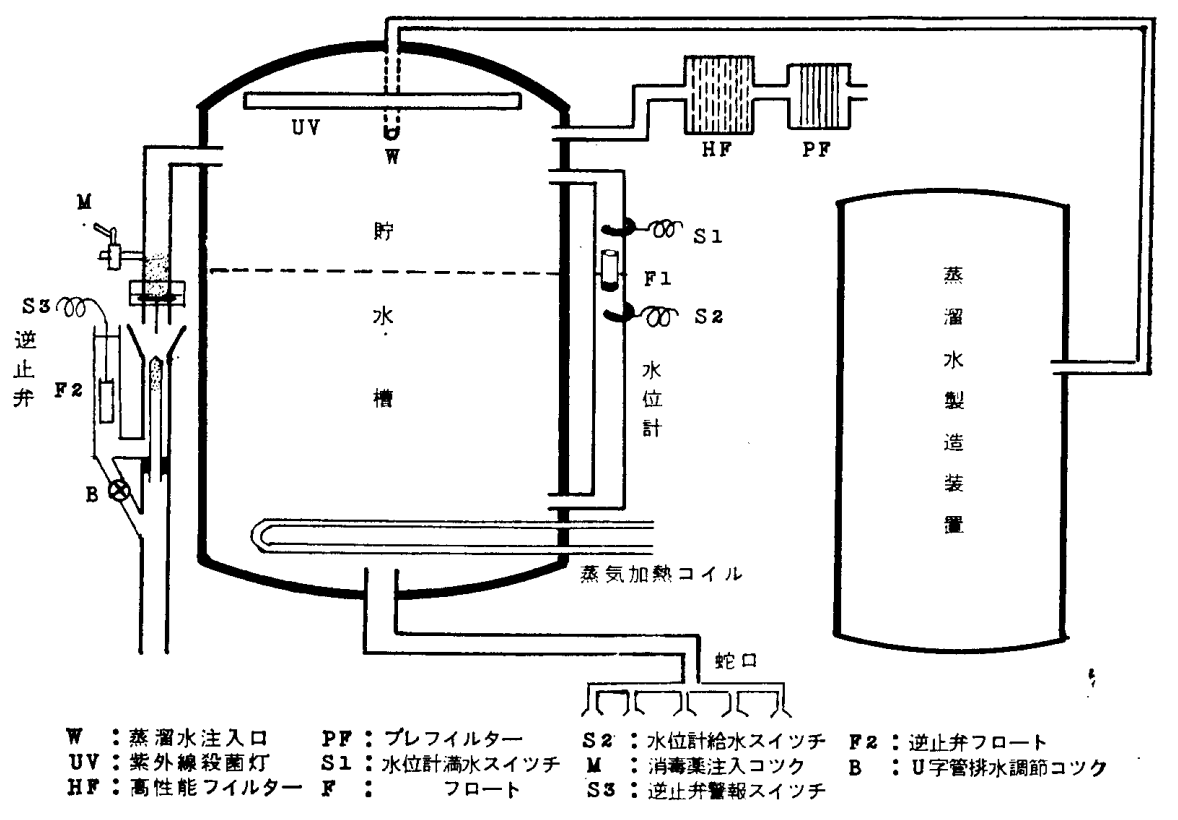

図 8 
(34)

滅菌力の不足ということになります.

水の精製法として蒸溜法の他に脱イオン法, 沪過, 逆浸透圧法, 殺菌法としては紫外線利用 などがありますが，私は蒸溜法という古典的で はあるが，歴史的な評価を得ている方法をとっ たわけであります。

その他に侵入路として貯水槽，配管等の装置 の細菌学的密封の不完全な箇所や回路の破損に よる污染があります.

わが国の今までの手術用滅菌水製造装置や蒸 溜水製造装置の貯水槽はこうした意味では全く 細菌学的密封に配虑が足りませんでした。

極端な表現が許されるならば，鍋か釜で水を 沸騰さして放置してそのまま冷し, 出来るだけ 污染されないうちに早く使用するという程度の ものであったといえます.

貯水槽の水は使用寸れば減少し液面は低下 し，槽内に外部より空気が流入します.

水の使用量が減少し製造量が多くなれば当 然, 槽内の水は増量し液面は上昇して槽内の空 気は排出されます.

水の增減で外部の空気が出たり入ったりする わけです.この空気の出入路が充分細菌学的な 配慮がされているかどらか, 開放されていたり フィルターがあっても綿ごみを取る程度のもの でしかなかったり, 空気の専用通路がなくて, 水位計のフロートの軸受けの隙間やオーバーフ ロー回路が開放されたままであったりしたわけ です.

更に污染の侵入路として考えられるのは, 開 放された回路の末端, 寸なわち手洗い蛇口から の逆行污染であります.

これに対する方法がないわけではありません が，この部分は装置全体の最終の回路部分なの で, 他の部分を改修したのち, 問題が残ればこ の部の改良を行なうことは容易なので, 蛇口を 含めて貯水槽以下の配管もそのまま残すことに いたしました。

\section{3. 具体的な改修の状態}

（1）貯水槽の空気出入口の設置とエアーフィ ルターについて

先にも述べましたように，貯水槽への空気の

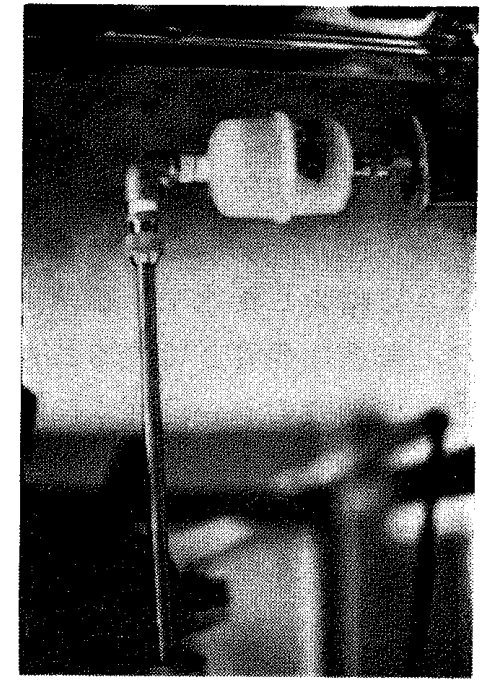

図 9

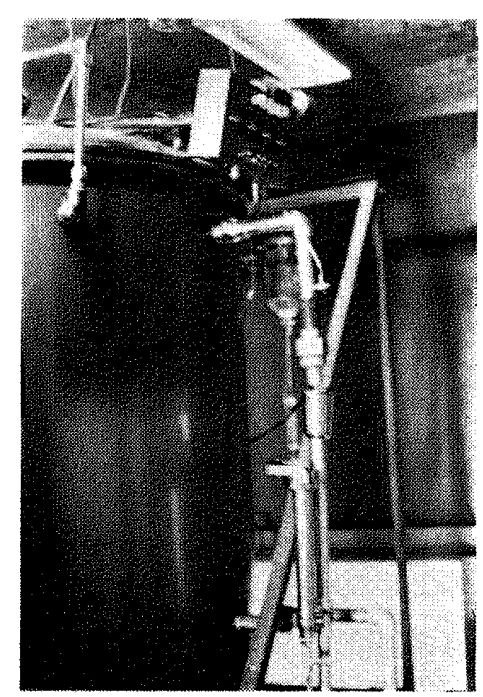

図 10 滅菌水装置改良

出入りは，必ず起こるものでありますから，そ のための専用回路をまずとるということ, 次で この回路の外気への開放部分に精度の高いフィ ルターを使用するということ。

このフィルターについては貯水槽内は常に水 が存在し, しかも手洗いに適当な $45^{\circ} \mathrm{C}$ 前後に加 温された水であるため, 槽の上部の空気は高温 多湿であることを考慮して湿気に強い材質の無 機ファイバーを用いたものが必要です.

また保守上，かび類の増殖によって連続的に フィルターの深部に污染が波及して行く危険性 があるということ,さらに耐久性という点から フィルターを 2 重にしてプレフィルターを用い ました。

このフィルターの直上 $10 \mathrm{~cm}$ の距離に, $19 \mathrm{w}$ 
の紫外線殺菌灯を付けました.

（フィルターは Pall 社製：ウルチポア DFA, MBY, 2001, UR)

\section{（2）貯水槽のオーバーフロー回路}

滅菌水，われわれの場合は蒸溜水ですが，そ の水が製造されて貯水槽に溜る場合，貯水槽の 水位を検知して蒸溜水製造装置を自動運転さす ようにしました。

しかし万一この水位の検知や製造装置の運転 制御が良好に作動しなかった場合には，貯水槽 に貯溜した水は空氮の出入口のフィルターに逆 流することになるためにオーバーフローの配管 をしました。

もし空気流入用フィルターにオーバフローし ますとフィルターが沪過によって集積した塵埃 や微生物と一緒に水が流通して, 細菌污染の延 長すなわち逆行污染の可能性が出てきます。

こうした意味で空気出入口の開放部より一段 低いところにオーバーフロ一回路をとり下方に 向けて配管しました。

この回路を細菌学的に封鎖する必要があるわ けですが，方法としてはフィルターの取り付 け，逆止弁による機械的な閉鎖，紫外線殺菌灯 の利用などが考えられますが，空気の専用出入 ロを別にしたこと.

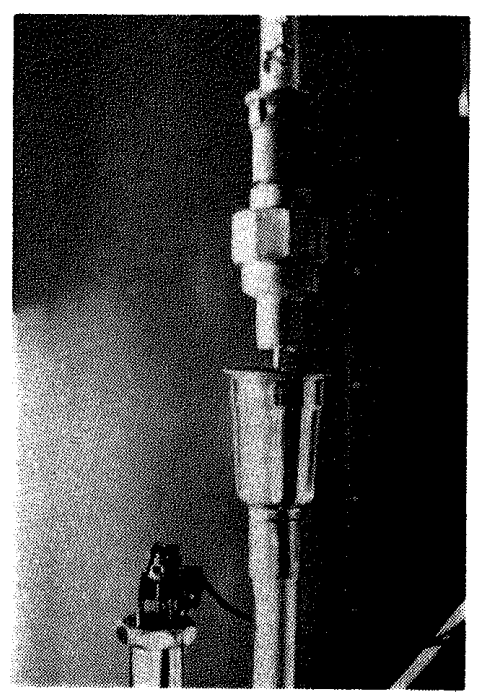

图 11

オーバーフローの管壁が結露によって，いつ も湿っていることが予想されるので，フィルタ 一を取りつけても何時も湿っているだろうとい うこと.
湿潤した管壁では紫外線もなかなか有効では なかろうと，いろいろ考えた上で，麻酔器の呼 気弁などに用いられる一方交通の逆止弁を取り 付けました.この弁は，スプリングによって一 定圧 $(5.0 \mathrm{~cm}$ 水柱）以上の圧がかかると弁が開 放されて排水するようにしました。

弁は，この構造のままでは細菌污染に対して は，不安があるので, 何時も消毒薬 (0.5\%ク口 ールヘキシジン液）が貯溜するようにしまし た.

この回路の閉鎮はより効果的で安全な方法が 他にあるかと思いますが，今のところこれで我 慢しています。

万一貯水槽がオーバーフローした場合は回路 が開放されるわけですから污染の危険が起こっ たことを通報するランプを点灯することにしま した.

弁の下方にあるU字管とその部のフロートが この役をいたします.オーバーフローしますと 警報ランプは，リセットボタンを押さないかぎ り点灯しつづけます. 設置後 7 カ月になります が，末だオーバーフローしたことはありませ ん.

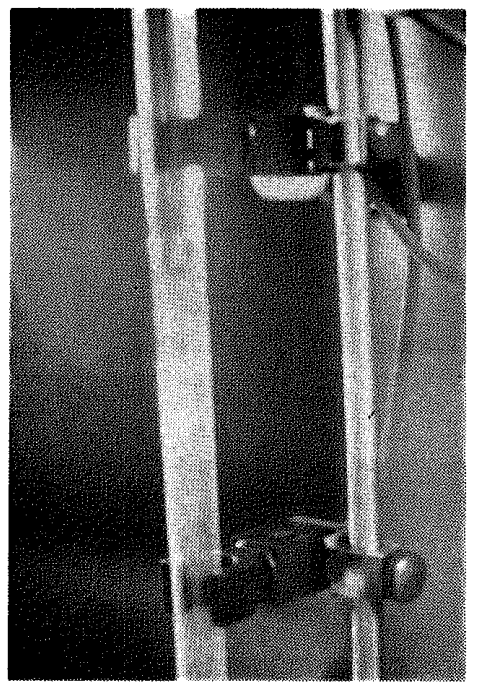

図 12

\section{（3）完全密封式水位計}

貯水槽内の水位をみたり，蒸溜水の製造の自 動運転の制御を行なうために水位計と水位によ る制御スイッチを必要とします。

こうした水位計も貯水槽と一体になった完全 密封式のものでなければなりません. 


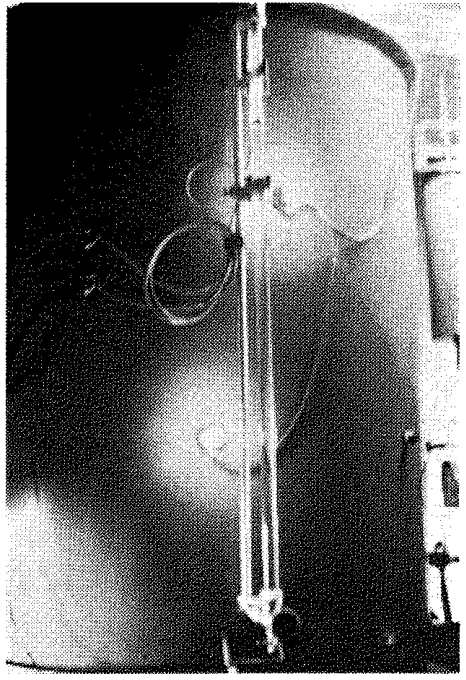

図 13 隇菌 水貯 水槽

そこで完全に外部と密封されたガラス管内を フロートが上下し，管壁外の端子が管内フロー トの磁力を感知する. オムロンの TL-H型近接 スイッチによる制御を採用しました.

(4) 貯水槽内の紫外線殺菌

貯水槽の考光得る細菌污染経路は一応全部遮 断したわけですが，更に何等かの原因で污染が

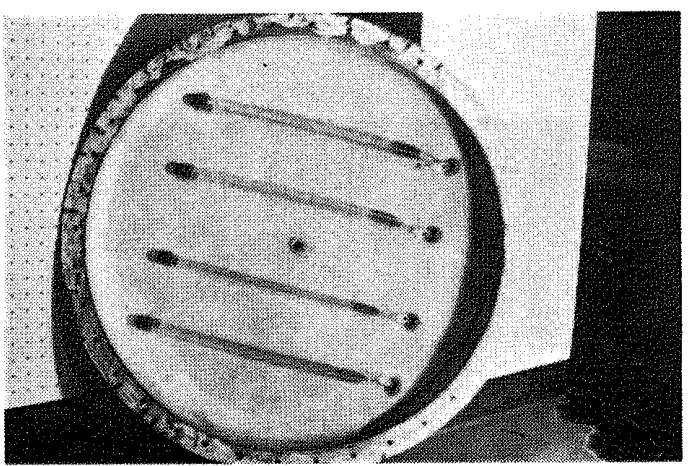

図 14

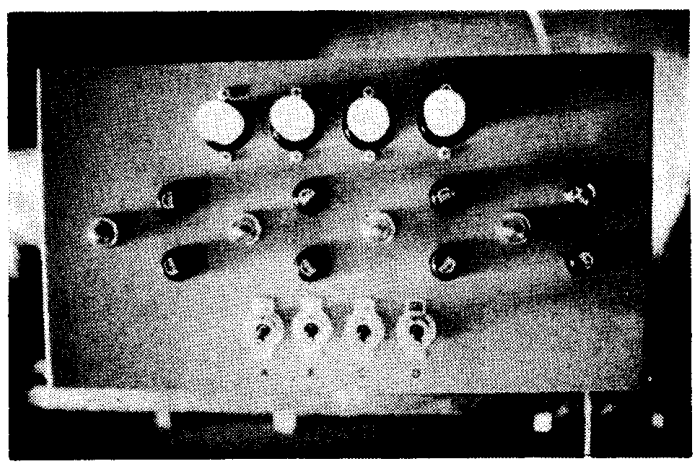

図 15

起こったときのことを考えて, 貯水槽の上部, 満水時の水位と上蓋との間隙が相当あるので上
蓋の裏面に紫外線灯殺菌を 4 本並列に取りつけ ました。

取りつけは湿度が高いことを考えてソケット 類は一切使用せずすべて值結しました.

この紫外線殺菌灯は，常時点灯しているわけ ですが，ステンレスの貯水槽のため外部よりそ れが点灯しているかどうか見ることが出来ない ので，外に各々の殺菌灯の点灯不良を警報する 指示ランプを取り付けました（図 16）殺菌灯 で注意しなければならないのは定格寿命は大体 3000 時間で, それ以上の時間点灯すると殺菌線 出力が安定時の70\%以下に低下することです。

たとえ点灯していても効力が落ちるので， 4 カ月〜 6 カ月ごとに交換する必要があります.

この点, 既存の貯水槽を使用したために殺菌 灯の交換には，その都度上蓋を取りはずさなけ ればならぬといら極めて不便なことになってし まいました。

（5）加温装置

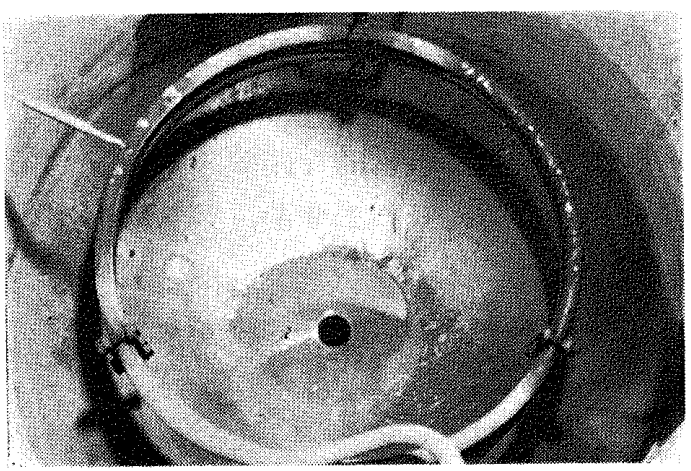

図 16 貯水槽内の鉄さび

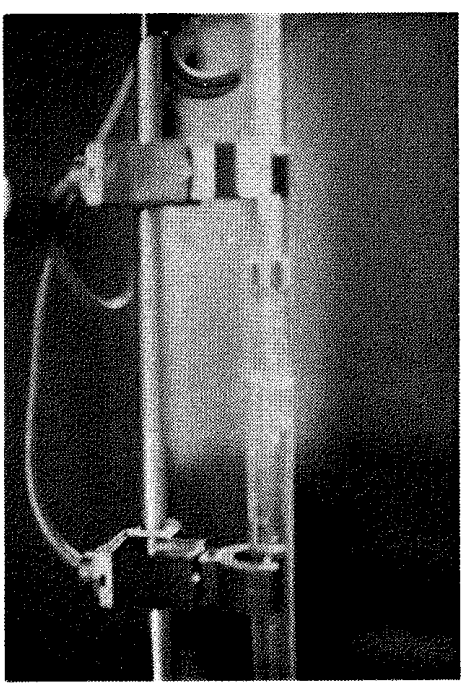

図 17 
既設の貯水槽の底にコイル式の蒸気による加 温装置と温度制御装置があり，これは完全に密 封されていて污染とは関係ないのでそのまま利 用しました。

\section{（6）鉄さびやスケールの問題}

従来, 簡単なイオン交換を行なった水道水を 募沸型の滅菌水製造装置を通していたわけです が，貯水槽の水位計のガラス管は掃除をして も，鉄さびのために1〜2 カ月で水位が見えな くなってしまいました.

この改修工事の際も貯水槽内の鉄さびやスケ ールはスライドのような状態でした.

これが蒸溜水を用いるようになってからは当 然のことではありますが， 6 力月たっても全く 清浄です.

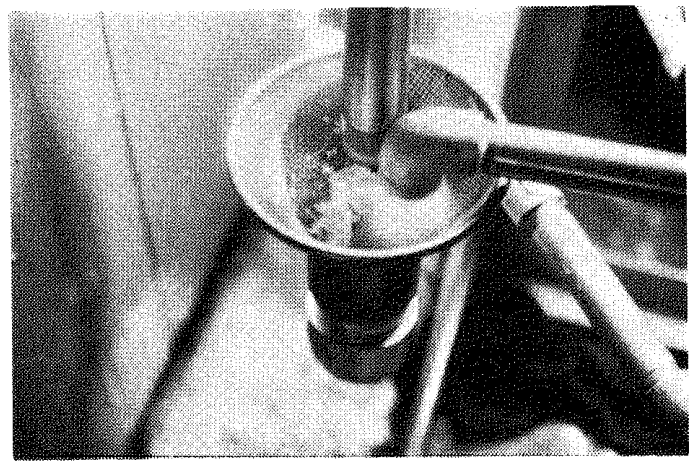

図 18 蒸溜水製造のスケール

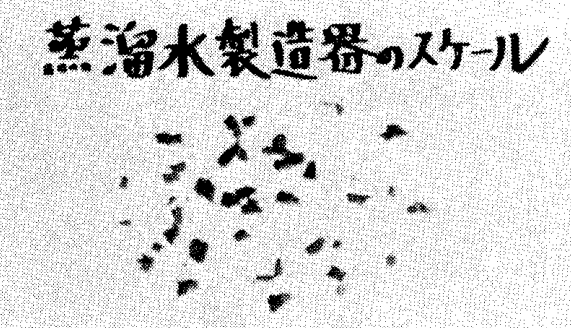

図 19

用いました蒸溜水製造装置では沸騰蒸発槽部 分にたまるスケールを除去することが可能で， 約 1 力月放置すると図のような排出状態がみら れます。

従来これらが沸騰槽を初めとして, 貯水槽や 配管内に附着したり沈澱し, 蛇口からも流れ出 ていたわけであります。

\section{（7）蒸溜水製造装置}

蒸溜水製造装置は図のような構造で，元圧 $4.0 \mathrm{~kg} / \mathrm{cm}^{2}$ の蒸気を用い運転時 $3.0 \mathrm{~kg} / \mathrm{cm}^{2}$ で, 冷却水圧 $2.0 \mathrm{~kg} / \mathrm{cm}^{2}$ で, 比抵抗 40 万オ一ム $/ \mathrm{cm}$

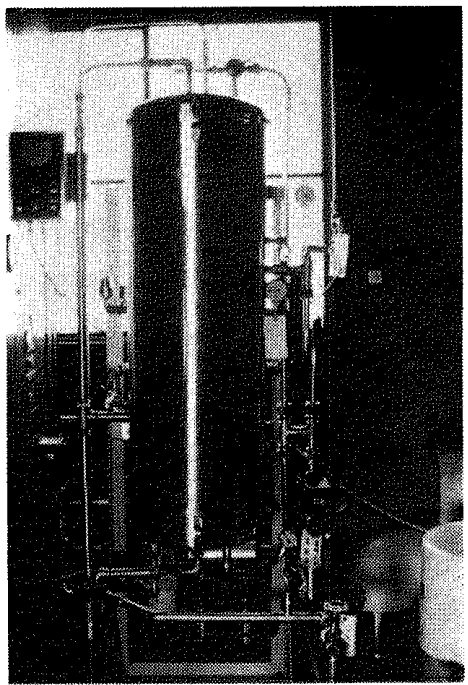

図 20 滅菌水蒸溜水装置

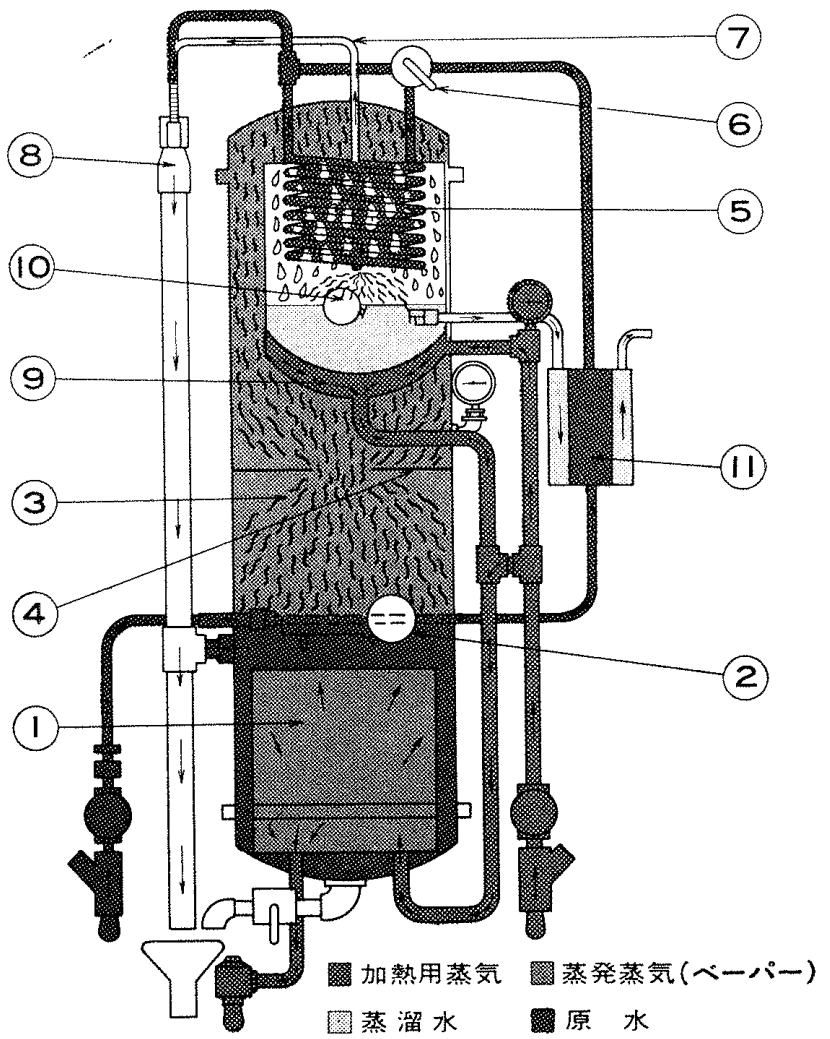

図 21
(1) 加 熱器
(2) 給水水位制御弁（自動排出弁）
(3) 上 昇 塔 (蒸発部)
(4) バッフル(邪魔板)
(5) 凝 縮 器 (冷却器)
(B) モノ・コントロールバルブ
(7) ガ ス 吸引管
(8) 水流ポンプ
(9) 蒸溜水加熱脱気槽
(10) 蒸溜水昍出制御弁
(11) 蒸溜水冷却器 
の水を毎時70 $l$ 製造するものを採用しました.

貯水槽が，満タン時 $427 l$ 貯水することが可 能で, 1 日 8 時間水を製造すれば $560 l$ 合計 $987 l$ 約 1 屯の水を使用することができるわけです.

普通 1 人の手洗いに $5 \sim 6 l$, 多くても $10 l$ の 使用ですから延べ人員 100 人の手洗いは可能な わけです。

われわれの手術部で 1 日70 90人の手洗いと $5 l$ の消毒薬約 20 本で $100 l$ 位の消毒薬稀䣋用水 を使っていますが，その他の用途をふくめても 充分な水量であります。

貯水量も無計画に大量になることは経済的に 無意味であるばかりか，水を長期に保存するこ とになるので水質の変化や污染の原因となり易 いので注意すべきかと考えます.

\section{4.おわりに}

改修後，貯水槽や配管を洗剤を用いて洗浄 後, 何回もすすぎ洗いをし，槽内に蒸溜水を溜 め, クロールヘキシジンで消毒した後, 最初の 貯水を行ない使用し初めました.

4 月初めより使用開始し, 当日, 翌日の検査 で菌は陰性, 以後 5 日ないし 7 日間隔で蛇口よ り採水して検查を続け， 6 月より 2 週間間隔で 培養していますが，10月初めまで無菌状態を持 続しています。

改修の要点は,

(1) 貯水槽に空気の出入口を付けこれに二重 のエアーフィルターをつけたこと
(2) 密封型の水位計と近接スイッチの使用

(3) オーバーフロ一回路をとり，これに逆止 弁をつけて, 更に消毒薬による污染防止, オーバーフロー警報装置

(4) 貯水槽の上葐内側に紫外線殺菌灯の取り 付け

(5) 蒸溜水を使用

(6) 改修箅所は，すべて安全確保のため 2 重 の制御を行なったことであります.

以上手術用滅菌水の細菌学的管理と題するに は，あまりにも㧍こがましいと思いますが，お れわれの実験的改修の経験をお話しいたしまし た. 水や空気の污染や，その清浄化ということ は，ある意味では永遠の課題であろらかと考え ます。

分析技術や学問の進歩によって次から次へと 問題が起こってくるものと思われます.

私どももこれでこの問題は解決したなどとは 考えて抢りません．むしろこれで良いのか，と いら疑問とそれに対応した検討を幅広く続けて おこなっていくつもりです.

現状での，さしあたっての問題解決の改修な り，改良と解釈して頂ければ幸いです。

以上で終りたいと思います．ご静聴ありがと うございました。

（編集部：注）

この論文は, 昭和 47 年 10 月 14 日札幌にて本学会 主催による第 18 回滅菌法研究会兼講演会の記録で す. 